\title{
Switches to English during French Service Encounters: Relationships with L2 French Speakers' Willingness to Communicate and Motivation
}

\section{Stephanie McNaughton E Kim McDonough}

This exploratory study investigated second language (L2) French speakers' service encounters in the multilingual setting of Montreal, specifically whether switches to English during French service encounters were related to L2 speakers' willingness to communicate or motivation. Over a two-week period, 17 French L2 speakers in Montreal submitted online questionnaires after they concluded service encounters that they had initiated in French. Their willingness to communicate in French was higher when the service provider did not switch to English; however, the frequency of English switches was not related to their general motivation to learn French. Possible reasons for language switches are explored, and pedagogical implications are highlighted.

Cette étude exploratoire porte sur des consultations qu'ont eues des locuteurs de français L2 dans le milieu plurilingue qu'est Montréal; plus précisément, les auteures se penchent sur la question de savoir si les transferts $d u$ français vers l'anglais pendant les consultations étaient liés à la volonté des locuteurs L2 à communiquer ou à la motivation. Au cours d'une période de deux semaines, 17 locuteurs de français L2 à Montréal ont complété des questionnaires en ligne après avoir eu des consultations qu'ils avaient initiées en français. Ils étaient plus motivés à communiquer en français quand le fournisseur de services ne passait pas à l'anglais; toutefois, la fréquence des transferts vers l'anglais n'était pas liée à leur motivation générale pour apprendre le français. Les auteures évoquent des raisons possibles pour le passage à l'anglais et en soulignent les répercussions pédagogiques.

It is largely acknowledged that second language (L2) learning is facilitated by being immersed in an environment where the target language can be used (MacIntyre, Baker, Clément, \& Donovan, 2003; Savignon, 2005). Immersion contexts provide opportunities for L2 speakers to be exposed to meaningful input and to produce the target language for a variety of authentic purposes. Despite the common belief that immersion contexts are beneficial because L2 speakers have opportunities to interact with locals, study-abroad research has reported divergent relationships between language gains and contact outside class (Hernandez, 2010; Segalowitz \& Freed, 2004). Furthermore, several 
studies have shown that L2 speakers may experience limited opportunities to interact with native speakers, and may favour speaking their own language with peers (Allen, 2010; DeKeyser, 2010; Freed, Segalowitz, \& Dewey, 2004; Isabelli-García, 2006; Wilkinson, 1998). Even if immersion contexts vary in terms of the extent to which L2 speakers have interactions with local residents, they do provide access to service encounters that, although brief, are frequent and are rich opportunities for L2 speakers to be socialized into new linguistic and cultural practices through daily social interactions (Duff, 2008; Shively, 2011, 2013). Service encounters - that is, exchanges for the purpose of obtaining goods and services in commercial establishments-require L2 speakers to communicate their needs for specific goods and services, often negotiating new interactional norms that differ from those in their first languages (Wang \& Mattila, 2010).

However, the potentially positive role for service encounters in L2 learning may not be realized in bilingual or multilingual environments. In such settings, code-switching, or the use of two or more languages within the same conversation (Bourhis, 1984), is frequently viewed as an effective way to communicate. If an L2 speaker initiates a service encounter in such settings, the service provider may switch to another language at some point in the conversation. The switch may occur because the service provider wishes to accommodate the customer whom they perceive as being a more proficient speaker of another language. Although this type of accommodation has largely been viewed positively by the recipient in some studies (Beebe \& Giles, 1984; Bourhis, 1984; Ylanne, 2008), it may be perceived negatively if the L2 speaker desires to use the target language (TL). Research has reported that accommodation through switching languages is not always appreciated (Callahan, 2009; Heller, 1982, 1992) because the L2 speaker may perceive the switch as a signal that they are not accepted as a member of the TL community. It is possible that the L2 speakers' perceptions about the service providers' language background may influence their reactions to a language switch. For example, if both the L2 speaker and the service provider are English L1 speakers, a language switch from French to English during a service encounter may not be perceived negatively.

For an L2 speaker, a successful service encounter may be interpreted positively as evidence that they have navigated a rite of passage and are integrating into the L2 community (Pellegrino Aveni, 2005; Shively, 2013; Siehl, Bowen, \& Pearson, 1992). In contrast, they may interpret a service encounter that triggers a language switch as rejection and may lead to avoidance of TL interaction during future service encounters (Wilkinson, 1998). For L2 speakers who live in multilingual environments, as opposed to students on short-term study abroad programs, experiencing repeated language switches may lead them to stop initiating service encounters in the L2, thereby further reducing their opportunities to interact with TL speakers. Put simply, experiencing language switches may affect L2 speakers' willingness to communi- 
cate in future encounters and may influence their general motivation to learn the L2 or integrate into the TL community.

L2 speakers' willingness to communicate, that is, their intention to speak or remain silent in a particular speech setting, is influenced by factors such as their perceived communicative competence, anxiety, and personality traits (Clément, Baker, \& MacIntyre, 2003; MacIntyre \& Charos, 1996; MacIntyre, Clément, Dörnyei, \& Noels, 1998). Willingness to communicate has also been linked to the attitudes of both the L2 speaker and the TL speech community, with positive attitudes facilitating successful interactions and linguistic self-confidence, and negative attitudes leading to more breakdowns in communication (Clément, Noels, \& Denault, 2001). Service encounters with an undesired language switch may lead L2 speakers to perceive their language competence negatively, increase their anxiety, and foster negative feelings toward the TL community, all of which may reduce their willingness to communicate in subsequent encounters.

Furthermore, service encounters with undesired language switches may lead to decreased motivation, such that there is a decline in an L2 speaker's previous interest or commitment to learning the language, or amotivation, which resembles apathy toward L2 use (Dörnyei, 2001). Undesired language switches may demotivate L2 learners because they highlight the contrast between learners' ideal selves (imagined or projected versions of themselves) and their present selves (Dörnyei \& Ushioda, 2009). Whereas motivated learners may respond to a language switch by striving to limit the gap between their actual and ideal selves, demotivated learners may respond by perceiving the switches as a negative commentary on their present selves and widening the perceived distance to their ideal selves. If members of the TL community are switching to another language during service encounters, L2 speakers may perceive the switches as a rejection, thereby further decreasing their motivation to use the TL.

The purpose of the current study was to explore the relationship between language switch during service encounters and L2 speakers' motivation and willingness to communicate. However, unlike study-abroad research that examines the temporally fixed experience of living in a TL community for the purpose of improving one's L2 skills, the current study focuses on L2 speakers of French who live in the multilingual context of Montreal. These L2 speakers moved to Montreal for employment, education, or family reasons, not specifically to improve their French skills, and intended to stay in the area for at least several years. As a result, their experiences with service encounters may differ from those of study-abroad students. Therefore, this smallscale exploratory study examines whether service encounters in multilingual settings provide L2 speakers with the language practice opportunities that have been previously documented in study-abroad settings (Shively, 2013). It investigated whether L2 French speakers experience switches to English during service encounters, and whether such language switches are related 
to their willingness to communicate or motivation to learn French. There were two research questions: (a) Is the willingness to communicate of French L2 speakers affected by language switch during service encounters? and (b) Is there a relationship between French L2 speakers' experience of language switches during service encounters and their motivation?

\section{Method}

\section{Context of the Study}

This exploratory study was carried out in Montreal, Québec. In Québec, French is the sole official language, and monolingual English speakers make up only $8 \%$ of the total population (Boberg, 2012; Dickinson, 2007; Hummel, 2013). Following the adoption of the Charter of the French Language, commonly referred to as Bill 101, French was firmly established as the language of public discourse, including government, public administration, education, industry, commerce, and other aspects of civic life. However, Montreal is the most linguistically diverse city in Québec, with the largest percentage of first-language speakers of English or other languages, and is largely perceived as a hub of French-English bilingualism (Bourhis, 1984; Heller, 1982, 1992; Kircher, 2014). Montreal also has the highest rate of multilingualism in Canada, with more than $40 \%$ of residents speaking three languages (Lamarre \& Dagenais, 2004). Montreal is also the preferred destination for immigrants to Québec, with $85 \%$ choosing to settle in the Montreal metropolitan area; furthermore, approximately $84 \%$ of the new arrivals from 2002 to 2006 declared a first language (L1) other than French or English (Hrimech, 2009).

\section{Participants}

The participants were 17 L2 French speakers (11 women, 7 men) who ranged in age from 24 to 61 years, with a mean of 31.4 years $(S D=8.8)$. They spoke a variety of L1s, including English (8), Spanish (6), Bulgarian (1), Russian (1), and Cantonese/English (1). Two participants were from Québec, but the others had moved there from other provinces or countries for education, work, or personal reasons, such as to be with friends or family. Their length of residence in Montreal ranged from six months to six years, with a mean of 2.7 years $(S D=1.9)$. Using a 9-point Likert scale $(1=$ poor, $9=$ fluent $)$, the participants self-assessed their French abilities as being 5.5 for speaking $(S D=2.0)$, 6.4 for reading $(S D=2.3), 5.9$ for listening $(S D=1.9)$, and 5.1 for writing $(S D=$ 2.1). The participants reported their satisfaction with living in Montreal and their French skills using a 6-point Likert scale $(1=$ completely dissatisfied, $6=$ completely satisfied). Their ratings indicated that whereas they were satisfied with life in Montreal generally $(M=5.0, S D=.5)$, they were somewhat dissatisfied with their French skills $(M=3.1, S D=1.3)$. 


\section{Materials}

Service encounter questionnaire. In order to tap into the dynamic and situationspecific nature of willingness to communicate (Dörnyei, 2009), a short online questionnaire was created using Survey Gizmo (www.surveygizmo.com) so the participants could use a mobile device to respond immediately after a service encounter. The questionnaire, which consisted of multiple-choice items and an open-ended question, could be completed by mobile phone, tablet, or computer. Several questions requested details about the service encounter, such as the location (grocery store, convenience store, restaurant, merchandise store, government services, or customer service), if and in which language the service provider greeted the participant, and whether the service provider switched to English. One question asked the participants if they had an impression of the service providers' language background, specifically whether they were a native speaker of Quebecois or another variety of French, a native speaker of English, or a native speaker of a language besides French or English. To assess the potential relationship between the service encounter experience and the participants' willingness to communicate, the last item on the questionnaire asked whether the encounter affected the participants' desire to speak French in their next service encounter. Five response options were provided, ranging from feeling definitely encouraged to speak French in a subsequent encounter to feeling definitely discouraged to speak French the next time. The item was designed to elicit the participants' perceptions about the willingness to speak French in future service encounters generally, rather than subsequent encounters with the same interlocutor or at the same specific business. The last item was an open-ended question about whether the participants had any additional information they wished to share about the encounter.

Motivation questionnaire. The motivation questionnaire assessed the participants' general levels of motivation for learning French, and was adapted from Dörnyei and Taguchi's (2010) motivation questionnaire. It was also administered using Survey Gizmo, and could be completed using a mobile phone, tablet, or computer. The original questionnaire was modified by reducing the number of items and editing the questions to reflect the local context of learning and speaking French in Québec. The adapted version contained 40 statements in eight categories that the participants indicated their agreement by using a 6-point Likert scale: strongly agree, slightly agree, agree, slightly disagree, disagree, or strongly disagree. The eight categories were criterion measures (i.e., efforts, interest, and readiness to invest time and energy into learning), ideal self (i.e., desired attributes), ought-to self (i.e., attributes to avoid negative outcomes), promotion orientation (i.e., working toward positive outcomes), prevention orientation (i.e., avoiding negative outcomes), attitudes toward learning French, interest in French, and French anxiety. The motivation questionnaire is provided in the Appendix. Instrument reliability 
was assessed through its internal consistency, based on Cronbach's alpha, which was .88 .

\section{Procedure and Analysis}

The participants were recruited through promotional posters and social media. They were contacted by e-mail and given instructions on how to access and use the online service encounter questionnaire. They were asked to complete a service encounter questionnaire immediately after they had a service encounter in which they initiated discourse in French over a twoweek period. Service encounters were defined as interactions involving an exchange of services or information that involved more language use than simple greetings or rote expressions and required several turns within the conversation. After the participants finished the two-week service encounter phase, they completed the motivation questionnaire.

The service encounter questionnaire responses were exported to SPSS for statistical analysis. First, the number of service encounters reported by each participant was totaled, with the number of encounters with and without a switch to English summed separately. Descriptive information about the encounters, such as the location, was compiled. Next, the participants' responses to the question about the effect of the service encounter on their willingness to communicate in French were converted into numeric values using the following scale: definitely encouraged $=5$, somewhat encouraged $=4$, no effect on my encouragement $=3$, somewhat discouraged $=2$, definitely discouraged $=1$. The participants' scores for switch and nonswitch encounters were then summed, and a mean score for each encounter type was calculated.

The motivation questionnaire responses were also exported from Survey Gizmo to SPSS for statistical analysis. Their responses were converted into numeric values using the following scale: strongly agree $=6$, agree $=5$, slightly agree $=4$, slightly disagree $=3$, disagree $=2$, strongly disagree $=1$. In order to ensure that high total values corresponded with high levels of motivation, all negatively worded statements were reverse scored. For example, a response of "strongly agree" to a positively worded statement (e.g., whenever I think of my future career, I imagine myself using French) was given a value of 6, but the same response to a negatively worded statement (e.g., the things I want to do in the future do not require me to use French) was given a value of 1 . The values for all 40 questions were summed, and mean scores for each category were calculated.

\section{Results}

\section{Overview of the Service Encounters}

The data set consisted of a total of 357 reported service encounters, ranging from 5 to 36 encounters per participant over a two-week period $(M=21$, 
$S D=10.5)$. The participants completed a majority of the service encounters (232/357, or 65\%) exclusively in French, whereas they experienced a switch to English during one-third of the encounters (35\%, 125/357). The mean number of service encounters exclusively in French per participant was $13.7(S D=$ 7.9), while the mean number of encounters with switches to English was 7.4 $(S D=4.9)$. As shown in Table 1 , their service encounters occurred in a variety of locations, with the most common being in grocery or convenience stores, merchandise stores, and restaurants. There was little difference in the location of service encounters carried out in French only versus those with a switch to English, with the exception that switches to English were less likely during transportation encounters.

Table 1

Service Encounter Locations by Language Use

\begin{tabular}{|c|c|c|c|c|}
\hline & \multicolumn{2}{|c|}{$\begin{array}{l}\text { French only } \\
\qquad(n=232)\end{array}$} & \multicolumn{2}{|c|}{$\begin{array}{l}\text { Switch to English } \\
\quad(n=125)\end{array}$} \\
\hline & Number & $\%$ & Number & $\%$ \\
\hline Grocery and convenience stores & 58 & 25 & 31 & 25 \\
\hline Merchandise stores & 47 & 20 & 23 & 18 \\
\hline Restaurants and cafes & 40 & 17 & 28 & 22 \\
\hline Transportation (bus, taxi, metro, train) & 25 & 11 & 4 & 3 \\
\hline Customer service (bank, phone, Internet, etc.) & 23 & 10 & 9 & 7 \\
\hline Government and health services & 10 & 4 & 8 & 6 \\
\hline $\begin{array}{l}\text { Other (work, school, hotel, deliveries, gas station, } \\
\text { gym) }\end{array}$ & 12 & 5 & 13 & 10 \\
\hline Unreported location & 17 & 7 & 9 & 7 \\
\hline
\end{tabular}

For both the exclusively French and switch to English encounters, the participants were greeted most often in French (see Table 2). However, when greeted in English or both languages, the participants were more likely to experience a switch to English (35\%) than encounters with Frenchonly greetings $(17 \%)$. The participants perceived the service providers as being L1 speakers of French for 74\% of the encounters in French, but for only $53 \%$ of the encounters with a switch to English. For the switch to English encounters, they perceived the service providers as being L1 speakers of English or another language (25\%) or stated that they did not know $(22 \%)$.

To summarize, these L2 speakers carried out the majority of their service encounters in French exclusively, and there was little difference in the location of their encounters with or without a language switch. However, their service encounters with a switch to English were more likely to begin with a greeting in English or both English and French. In addition, when the service 
encounters had a switch to English, the participants were more likely to perceive the service providers as not being L1 speakers of French.

Table 2

Service Providers' Greeting and Perceived Language Background by Language Use

\begin{tabular}{|c|c|c|c|c|}
\hline & \multicolumn{2}{|c|}{$\begin{array}{l}\text { French only } \\
(n=232)\end{array}$} & \multicolumn{2}{|c|}{$\begin{array}{l}\text { Switch to English } \\
\quad(n=125)\end{array}$} \\
\hline & Number & $\%$ & Number & $\%$ \\
\hline \multicolumn{5}{|l|}{ Greeting } \\
\hline French & 170 & 73 & 68 & 54 \\
\hline English & 9 & 4 & 14 & 11 \\
\hline Both & 31 & 13 & 30 & 24 \\
\hline None & 5 & 2 & 4 & 3 \\
\hline Not reported & 17 & 7 & 9 & 7 \\
\hline \multicolumn{5}{|l|}{ Perceived L1 background } \\
\hline Quebecois French & 126 & 54 & 43 & 34 \\
\hline Other variety of French & 47 & 20 & 24 & 19 \\
\hline English & 14 & 6 & 19 & 15 \\
\hline Neither French nor English & 18 & 8 & 12 & 10 \\
\hline Don’t know & 27 & 12 & 27 & 22 \\
\hline
\end{tabular}

\section{Language Switch, Willingness to Communicate, and Motivation}

The first research question asked whether French L2 speakers' willingness to communicate was affected by switches to English during service encounters. To address this question, the participants' willingness to communicate scores following switch and nonswitch encounters were summed and average scores were obtained for each type. The participants' willingness to communicate score was higher for service encounters in French $(M=4.1, S D$ $=.4)$ than encounters with a switch to English $(M=2.9, S D=.6)$. A pairedsamples $t$-test indicated that their willingness to communicate was significantly higher after French-only service encounters $[t(16)=6.27, p=.001)]$ with a large effect size (Cohen's $d=2.4$ ). Put simply, the participants felt more encouraged to speak French in future encounters when a service encounter was carried out entirely in French and the service provider did not switch to English.

To gain further insight into the participants' willingness to communicate, their scores for switch and nonswitch encounters were also compared based on their perceptions about the service providers' language background. As mentioned previously, it is possible that the participants' willingness to speak French might be less affected by switches to English if they perceived the 
service provider as being a fellow English L1 or French L2 speaker. However, as shown in Table 3, the participants' willingness to communicate was consistently lower after encounters with a switch to English regardless of the service providers' perceived language background. The difference in scores was the greatest when they perceived the service provider as being a speaker of Quebecois French or English.

Table 3

Willingness to Communicate by Language Switch and Service Providers' Perceived Language Background

\begin{tabular}{lccllll}
\hline & \multicolumn{2}{c}{ Switch to English } & & \multicolumn{2}{c}{ No switch } \\
\cline { 2 - 3 } \cline { 6 - 7 } & Mean & $S D$ & & Mean & $S D$ \\
\hline Quebecois French & 2.97 & .62 & & 4.23 & .41 \\
Other variety of French & 3.42 & .84 & & 3.88 & .70 \\
English & 2.71 & .45 & & 3.60 & .89 \\
Neither French nor English & 3.42 & .65 & & 4.19 & .81 \\
Don't know & 3.15 & .54 & & 3.93 & .46 \\
\hline
\end{tabular}

The second research question asked whether there was a relationship between French L2 speakers' motivation to learn French and the frequency of service encounters with a switch to English. The participants' motivation scores are provided in Table 4 , with scores for items in each category summed and averaged (possible scores ranged from 1 to 6). For each category, the item's internal consistency (Cronbach's alpha) is provided in parentheses. The participants' lowest scores were for the ought-to self and prevention orientation items, while their highest scores were for interest in French, attitudes toward learning French, and the criterion measures.

Table 4

Mean Motivation Scores by Category

\begin{tabular}{lcc}
\hline Category & Mean & $S D$ \\
\hline Criterion measures $(.54)$ & 4.6 & .7 \\
Ideal self $(.51)$ & 4.2 & .8 \\
Ought-to self $(.80)$ & 3.9 & 1.0 \\
Promotion orientation (.65) & 4.2 & .8 \\
Prevention orientation (.73) & 3.6 & 1.1 \\
Attitudes toward learning French (.41) & 4.6 & .6 \\
Interest in French $(.67)$ & 4.6 & .7 \\
French anxiety (.80) & 4.2 & .9 \\
All 40 items $(.88)$ & 4.2 & .5 \\
\hline
\end{tabular}


In order to reduce the number of statistical comparisons, only the participants' aggregate motivation score for all 40 items was correlated with the proportion of service encounters they experienced with a switch to English (switch encounters/all encounters). A Pearson correlation indicated that although there was a negative relationship between language switch service encounters and motivation, it was not statistically significant, $r(17)=-.29, p$ $=.26 .{ }^{1}$ In other words, the frequency of service encounters with switches to English was not related to the L2 speakers' overall motivation for learning French.

\section{Discussion}

To summarize the findings, the majority of the service encounters experienced by these L2 French speakers were carried out in French, with only one-third of their encounters characterized by a service provider's switch to English. Thus, the experience of these L2 speakers in the multilingual context of Montreal confirm the study-abroad research suggesting that service encounters can provide meaningful opportunities to practice L2 skills (Hernandez, 2010; Shively, 2011, 2013). However, when service providers switched to English, the L2 speakers reported lower willingness to communicate in French for future service encounters. Despite their negative impact on the participants' willingness to communicate, service encounters with switches to English were not related to their overall motivation to learn French. In other words, the participants' motivation level at the end of the data collection period did not have any relationship with their experience of language switches. For example, some participants who experienced a high rate of language switches (more than $60 \%$ of their service encounters) reported higher motivation levels than participants who rarely experienced a switch (less than 25\%). One possibility is that regardless of how often language switches occurred, these L2 speakers were able to maintain their motivation to learn French and perpetuate their ideal selves as French speakers (Dörnyei \& Ushioda, 2009). Another possibility is that the questionnaire elicited the participants' general disposition or trait motivation, which may be sufficiently complex and stable to withstand fluctuations in their willingness to communicate as triggered by service encounters with language switches.

Although service encounters with a switch to English accounted for only $35 \%$ of the data, it raises interesting questions about why the service providers elected to switch languages even after the L2 speakers initiated conversations in French. As mentioned previously, French is the sole official language of Québec, and it is promoted as the only language for public discourse. However, recent studies have claimed that a Montreal identity has emerged that is characterized by greater heterogeneity than is found in the rest of Québec and by the identification of English as a common assumed in-group language between linguistic groups (Kircher, 2014; Labelle \& Salée, 2001; 
Lamarre, Paquette, Kahn, \& Ambrosi, 2002). In light of the diversity of the participants' language backgrounds and the Montreal population generally, the service providers may have switched to English due to visual or auditory cultural markers (Callahan, 2009; Heller, 1982, 1992) that led them to perceive the participants as being speakers of other languages. For example, several participants noted that the service providers switched to Spanish, presumably because they perceived (correctly) that the participants were speakers of that language. Nevertheless, these participants reported lower willingness to communicate even when they perceived the service providers as being English speakers, which suggests that they may not have appreciated the interlocutors' efforts to accommodate them by switching from French to English.

Another potential explanation for the service providers' switches to English is that they were oriented toward efficiency, that is, the desire to accomplish the exchange with minimal effort and maximal speed. The service provider's orientation toward efficiency was mentioned by several participants in their reports of encounters with a switch to English. For example, a participant reported speaking French at a fast food restaurant and the cashier switched to English. In the open-ended question he accounted for the switch as follows:

I think that she didn't understand some words I said and there was a lot of people behind me, so she just wanted to do very quickly and she thought that if my French was not good at least I might be able to reply in English.

Similarly, another participant attributed the need for efficacy as the cause for the switch to English by explaining, "The supermarket was super busy. I got the sense that the cashier switched so she could get me through the line as fast as possible." They also attributed a switch to English to service efficiency when the interaction deviated from the typical service exchange or went "off-script." When describing a service encounter at a grocery store, one participant explained that it had been a

pretty routine check-out experience, which I'm usually prepared for, but then the clerk asked me if I'd like to make a donation to a charity.

I didn't understand at first so she switched to English. I kept going in

French, but she used English for the rest of the time.

Another participant commented that although routine encounters were in French, when he was asked "different questions that were not part of the routine conversation," then a switch to English was more likely. In sum, comments in the service encounter questionnaire indicated that the participants attributed some switches to English to the service provider's desire to complete the transaction quickly and efficiently, particularly if the transaction involved an off-script exchange. 
Another possible explanation for switching concerns the ideas of "wecode" and "they-code" (Gumperz, 1982; Seba \& Wootton, 1998). For example, in Heller's Montreal-based studies $(1982,1992)$, interlocutors negotiated language choice based on identity and their perceptions of who belonged to their "in-group." More specifically, if French L1 speakers perceived their interlocutors as English L1 speakers, they preferred to speak English. However, if they perceived the interlocutors as fellow French L1 speakers, then they preferred to continue the conversation in French. Considering the current study was also carried out in Montreal, it is possible that some service providers were maintaining the status of their "in group" by withholding opportunities for French L2 speakers to speak French. However, this possibility is not supported by the participants' perceptions of the service providers' L1 background. Although the service providers' actual language background is unknown, the participants perceived them as being L1 French speakers more frequently when the service encounter was carried out exclusively in French. When the service providers switched to English, they were more likely to describe them as being fellow French L2 speakers. If the participants' perceptions were accurate, it suggests that the French L1 speakers were not withholding opportunities for L2 French speakers to use the target language. In contrast, the French L1 speakers were providing opportunities for L2 French use by not switching to English.

An additional potential explanation is that the participants positioned the service providers who switched to English as L2 speakers of French in order to preserve their own self-image. In other words, rather than attribute the language switch to gaps in their own communicative competence, the participants believed that it was due to the service providers' command of French. For example, one participant suggested that the service provider switched to English because "this area is more Anglophone ... they do not know how to speak French." Similarly, another participant explained the switch to English by questioning "whether the grocery store employee spoke French." These explanations may reflect the L2 speakers' attempts to minimize the gap between their ideal L2 self (i.e., a competent French speaker) and how the language switch encounter made them view their actual selves (i.e., a less than competent French speaker) (Dörnyei \& Ushioda, 2009). The participants may have attributed the cause of the switch to an external catalyst rather than their own language skills in order to maintain a positive view of their actual selves and sustain their confidence to initiate future encounters in French (Pellegrino Aveni, 2007; Spratt, Humphreys, \& Chan, 2002).

\section{Implications}

The quantitative findings and the participants' comments on the questionnaires point to several potential pedagogical implications. Since these L2 speakers had greater willingness to communicate when their interlocutors 
did not switch to English, L2 instructors might highlight communication strategies that students can employ to avoid switches or to maintain TL communication when confronted with a language switch. Several participants remarked that they persisted in speaking French even after the service providers switched to English, and explained that they simply told the service provider that they were "working on speaking French and wanted to practice" or "I stayed in French and told her I was sorry for my French but that I wanted to practice." By raising awareness of the language switch phenomenon and focusing on communication strategies (such as those highlighted by Savignon and Sysoyev, 2005), L2 instructors can help prepare students for encounters in which their interlocutors switch to English (Callahan, 2009).

In light of the participants' perception that "off-script" interactions triggered the service providers' switches to English, it may be helpful to provide students with opportunities to engage in conversations when an interlocutor deviates from the standard routine. For example, after students have practiced the routinized language associated with specific speech events, such as interacting with a service provider in a restaurant, conversations could become more complex by introducing off-script elements, such as food allergies, menu substitutions, or being out of ingredients. Introducing students to the more specialized vocabulary needed for less frequent service encounters may also reduce language switches triggered by a lack of vocabulary knowledge. For example, the participants remarked that switches to English occurred after they code-switched to an English word during infrequent speech events, such as obtaining health services, scheduling deliveries, and replacing print cartridges. Having practice reacting to novel or unexpected content that arises during routine encounters and encounters that require specialized vocabulary may prepare students for off-script exchanges and help them maintain or restore L2 communication.

The participants' positive reactions to the experience of reporting and reflecting on their service encounters suggests that it may be useful for L2 instructors to encourage students to document and reflect on their efforts to use the L2 outside the classroom. Several participants remarked in the motivation questionnaire that taking part in the study was a positive experience because keeping track of their interactions in French "motivated me to speak more French than usual" or "helped me to be more confident to start and keep a conversation in French." In the multilingual setting of Montreal, conversations in French occur with a wide variety of French speakers, ranging from L1 speakers of Quebecois French, L1 speakers of other varieties of French, to L2 speakers of French from numerous L1 backgrounds. The participants highlighted this diversity in their service encounter questionnaires, often pointing out that they perceived the service providers as being L1 speakers of languages other than French or English (Russian, Spanish, Portuguese, Hindi, Italian) and spoke different varieties of French (from Québec, France, Algeria). In some instructional settings, it may not be possible for students to 
use the L2 outside the classroom for service encounters or other face-to-face communication. In such settings, encouraging students to interact with other French speakers using technology (chat, blogs, Skype, etc.) may similarly foster motivation and confidence.

\section{Limitations and Future Research}

The findings of this exploratory study indicated that L2 French speakers' willingness to communicate was lower after service encounters with a switch to English, but their general motivation to learn French was not related to language switches. However, several limitations should be acknowledged. First, although the participants were representative of L2 French speakers in Montreal, the small sample size and the absence of any true beginners from the study limit the generalizability of the findings. A larger sample would have resulted in greater power, which may have revealed relationships between motivation and willingness to communicate. Future studies should target a larger sample of L2 speakers with more diverse L1 backgrounds and proficiency levels, which would allow for a clearer understanding of whether these learner characteristics play a role in language switches during service encounters, willingness to communicate, and motivation. Second, the multilingual setting of Montreal creates conditions that make language switches during service encounters possible. Because both the service providers and the participants had a variety of languages available to them, it is natural that they would draw upon these resources to facilitate efficient communication. As a result, the findings are not generalizable to contexts where service providers and L2 speakers have fewer languages at their disposal, and future research should explore how L2 speakers navigate service encounters in those contexts.

The current study relied on self-reported data to gather information about the participants' service encounters. By using a brief, online questionnaire to elicit the participants' immediate perceptions about their service encounters, the goal was to tap into the dynamic and situation-specific nature of willingness to communicate. The electronic format was provided to encourage greater participation by catering to participant convenience, but some participants may have found the electronic format burdensome. Future studies could address this issue by providing participants with the option of completing online questionnaires or filling out a hard-copy questionnaire booklet that could be submitted in person or by mail. Given that the current study focused on the L2 speakers' reports and perceptions about service encounters, future research might explore the perceptions of the service providers to gain more insight into why they switch languages (for insights into service providers' impressions of intercultural encounters, see Wang \& Mattila, 2010).

Finally, the participants' motivation may have been influenced by their participation in the study. Because the motivation questionnaire was administered at the end of the service encounter data collection period, it is 
possible that their responses were affected by the experience of documenting and reflecting on their use of French. Furthermore, while the correlation analysis provided insight into the relationship between the frequency of language switches and motivation, it does not imply causality. More tightly controlled experiments would be needed to assess whether participants' motivation levels were affected by their experience of language switch. Future studies could administer motivation questionnaires both before and after the data collection, which would provide insight into whether participating in research studies that encourage TL interactions has an effect on L2 speakers' motivation to learn the target language.

\section{Conclusion}

The findings indicated that French L2 speakers' willingness to communicate in service encounters in the multilingual setting of Montreal was higher when the service providers did not switch to English. The frequency of service encounters with a language switch was not related to the L2 speakers' overall motivation to learn French. This finding suggests that the L2 speakers were able to maintain their general motivation and persist in their efforts to learn French, despite experiencing occasional language switches. Although service encounters may not be considered the most desirable component of the immersion experience, as compared to interactions with coworkers, friends, or significant others, they do provide a reliable and consistent venue for the development of L2 communication skills. Once L2 speakers have acquired the linguistic and pragmatic skills necessary to successfully complete service encounters, they may build upon their skills by incorporating other social functions into their conversations, such as relational talk and nonobligatory conversations about products or services, as has been shown to occur in previous service encounter research (Schau, Delande, \& Gilly, 2007; Shively, 2013). In the voice of one participant, "This encounter was my longest interaction in French with a stranger so far. The conversation only lasted maybe 5-6 minutes but that's big for me." Our future research aims to further clarify how service encounters not only relate to L2 speakers' affective characteristics, but also serve as a catalyst for their language development.

\section{Note}

1 In response to a reviewer's query, we examined whether any of the individual variables measured on the motivation questionnaire had a relationship with language switches. Similar to the results for the motivation aggregate score, each variable had a negative relationship with language switches, but none of the correlations were significant, with $r$ values ranging from .04 to 30 .

\section{Acknowledgements}

This manuscript reports findings from the first author's MA thesis (McNaughton, 2014), which was funded by the Social Sciences and Research Council of Canada. We would like to thank the 
faculty members who participated in the thesis project, Walcir Cordoso, Elizabeth Gatbonton, and Pavel Trofimovich, for their helpful advice and feedback. We would like to thank the participants for their generosity in taking the time to be involved in the study. Without their willingness to share their experiences, this study would not have been possible.

\section{The Authors}

Stephanie McNaughton is a teacher at Centennial Academy in Montreal. She completed an MA in Applied Linguistics at Concordia University in 2014. Her research interests include learner motivation and sociological perspectives on the acquisition process.

Kim McDonough is a Professor and Canada Research Chair in Applied Linguistics at Concordia University. Her research interests include interaction and usage-based approaches to second language acquisition, structural priming, and task-based language teaching.

\section{References}

Allen, H. (2010). Language-learning motivation during short-term study abroad: An activity theory perspective. Foreign Language Annals, 43(1), 27-49. doi:10.1111/j.1944-9720.2010.01058.x

Beebe, L., \& Giles, H. (1984). Speech-accommodation theories: A discussion in terms of secondlanguage acquisition. International Journal of the Sociology of Language, 46, 5-32. doi:10.1515/ ijsl.1984.46.5

Boberg, C. (2012). English as a minority language in Québec. World Englishes, 31(4), 493-502. doi:10.1111/j.1467-971X.2012.01776.x

Bourhis, R. (1984). Cross-cultural communication in Montreal: Two field studies since Bill 101. International Journal of the Sociology of Language, 46, 33-47. doi:10.1515/ijsl.1984.46.33

Callahan, L. (2009). Accommodation to outgroups members' use of an in-group language: A comparison of service encounters in person and over the phone. International Multilingual Research Journal, 3(1), 1-15. doi:10.1080/19313150802668215

Clément, R., Baker, S., \& MacIntyre, P. (2003). Willingness to communicate in a second language: The effects of context, norms, and vitality. Journal of Languages and Social Psychology, 22(2), 190-209. doi:10.1177/0261927X03022002003

Clément, R., Noels, K., \& Denault, B. (2001). Inter-ethnic contact, identity, and psychological adjustment: The mediating and moderating roles of communication. Journal of Social Issues, 57(3), 559-577. doi:10.1111/0022-4537.00229

DeKeyser, R. (2010. Monitoring processes in Spanish as a second language during a study abroad program. Foreign Language Annals, 43(1), 80-92. doi:10.1111/j.1944-9720.2010.01061.x

Dickinson, J. (2007). The English-speaking minority of Québec: A historical perspective. International Journal of the Sociology of Language, 185, 11-24. doi:10.1515/IJSL.2007.023

Dörnyei, Z. (2001). Teaching and researching motivation. Harlow, UK: Pearson.

Dörnyei, Z. (2009). The L2 motivational self system. In Z. Dörnyei \& E. Ushioda (Eds.), Motivation, language identity and the L2 self (pp. 9-42). Bristol: Multilingual Matters.

Dörnyei, Z., \& Taguchi, T. (2010). Questionnaires in second language research: Construction, administration, and processing. New York: Routledge.

Dörnyei, Z., \& Ushioda, E. (2009). Motivation, language identities and the L2 self: Future research directions. In Z. Dörnyei \& E. Ushioda (Eds.), Motivation, language identity and the L2 self (pp. 350-356). Bristol: Multilingual Matters.

Duff, P. (2008). Language socialization. In P. Duff \& N. Hornberger (Eds.), Encyclopedia of language and education, Volume 8: Language socialization (pp. xiii-xix). New York: Springer.

Freed, B., Segalowitz, N., \& Dewey, D. (2004). Context of learning and second language fluency in French: Comparing regular classroom, study abroad, and intensive domestic immersion programs. Studies in Second Language Acquisition, 26(2), 275-302. doi:10.1017/S0272263104262064

Gumperz, J. (1982). Discourse strategies. New York, NY: Cambridge University Press 
Heller, M. (1982). The politics of codeswitching and language choice. In J. Gumperz (Ed.), Language and social identity (pp.108-118). New York: Cambridge University Press

Heller, M. (1992). The politics of codeswitiching and language choice. In C. M. Eastman (Ed.). Codeswitching (pp.123-142). Bristol: Multilingual Matters.

Hernandez, T. (2010). Promoting speaking proficiency through motivation and interaction: The study abroad and classroom learning contexts. Foreign Language Annals, 43(4), 650-670. doi:10.1111/j.1944-9720.2010.01107.x

Hrimech, M. (2009). Perspectives on adult education in Québec. New Directions for Adult and Continuing Education, 124, 37-48. doi:10.1002/ace.351

Hummel, K. (2013). Target-language community involvement: Second-language linguistic selfconfidence and other perceived benefits. Canadian Modern Language Review, 69(1), 65-90.

Isabelli-García, C. (2006). Study abroad social networks, motivation and attitudes: implications for second language acquisition. In M. DuFon \& E. Churchill (Eds.), Language learners in study abroad contexts (pp. 231-258). Clevedon: Multilingual Matters.

Kircher, R. (2014). Thirty years after Bill 101: A contemporary perspective on attitudes towards English and French in Montreal. Canadian Journal of Applied Linguistics, 17, 20-50.

Labelle, M., \& Salée, D. (2001). Immigrant and minority representations of citizenship in Quebec. In T. Aleinikoff \& D. Klusmeyer (Eds.), Citizenship today: Global perspectives and practices (pp. 279-315). Washington, DC: Brookings Institution Press.

Lamarre, P., \& Dagenais, D. (2004). Language practices of trilingual youth in two Canadian cities. In C. Hoffmann \& J. Ytsma (Eds.), Trilingualism in family, school and community (pp. 53-74). Clevedon, UK: Multilingual Matters.

Lamarre, P., Paquette, J., Kahn, E., \& Ambrosi, S. (2002). Multilingual Montreal: Listening in on the language practices of young Montrealers. Canadian Ethnic Studies/Études ethniques au Canada, 34(3), 47-75.

MacIntyre, P., Baker, S., Clément, R., \& Donovan, L. (2003). Talking in order to learn: Willingness to communicate and intensive language programs. Canadian Modern Language Review, 59(4), 589-607. doi:10.3138/cmlr.59.4.589

MacIntyre, P., \& Charos, C. (1996). Personality, attitudes, and affect as predictors of second language communication. Journal of Language and Social Psychology, 15, 3-26.

MacIntyre, P., Clément, R., Dörnyei, Z., \& Noels, K. (1998). Conceptualizing willingness to communicate in a L2: A situational model of L2 confidence and affiliation. Modern Language Journal, 82(4), 545-562. doi:10.1111/j.1540-4781.1998.tb05543.x

McNaughton, S. (2014). Switching to English: Effects on motivation to use L2 French in Montreal (Unpublished master's thesis). Concordia University, Montreal, Canada.

Pellegrino Aveni, V. (2005). Study abroad and second language use: Constructing the self. Cambridge: Cambridge University Press.

Pellegrino Aveni, V. (2007). Speak for your self: Second language use and self-construction during study abroad. In S. Wilkinson (Ed.), Insights from Study Abroad for Language Programs (pp. 99-113). Boston: Thomson Heinle.

Savignon, S. (2005). Communicative language teaching: strategies and goals. In E. Hinkel (Ed.), Handbook of research in second language teaching and learning (pp. 635-651). Mahwah, NJ: Lawrence Erlbaum.

Savignon, S., \& Sysoyev, P. (2005). Cultures and comparisons: Strategies for learners. Foreign Language Annals, 38(3), 357-365. doi:10.1111/j.1944-9720.2005.tb02222.x

Schau, H., Dellande, S., \& Gilly, M. (2007). The impact of code switching on service encounters. Journal of Retailing, 83(1), 65-78. doi:10.1016/j.jretai.2006.10.008

Seba, M., \& Wootton, T. (1998). We, they and identity. In P. Auer (Ed.) Code-Switching in conversation: Language, interaction and identity. (pp. 262-286) London: Routledge.

Segalowitz, N., \& Freed, B. F. (2004). Context, contact, and cognition in oral fluency acquisition: Learning Spanish in at home and study abroad contexts. Studies in Second Language Acquisition, 26(2), 173-199. doi:10.1017/S0272263104262027 
Shively, R. (2011). L2 pragmatic development in study abroad: A longitudinal study of Spanish service encounters. Journal of Pragmatics, 43(6), 1818-1835. doi:10.1016/j.pragma.2010.10.030

Shively, R. (2013). Out-of-class interaction during study abroad: Service encounters in Spain. Spanish in Context, 10(1), 53-91. doi:10.1075/sic.10.1.03shi

Siehl, C., Bowen, D., \& Pearson, C. (1992). Service encounters as rites of integration: An information processing model. Organization Science, 3(4), 537-555. doi:10.1287/orsc.3.4.537

Spratt, M., Humphreys, G., \& Chan, V. (2002). Autonomy and motivation: Which comes first? Language and Teaching Research, 6(3), 245-266. doi:10.1191/13621688021r106oa

Wang, C., \& Mattila, A. (2010). A grounded theory model of service providers' stress, emotion, and coping during intercultural service encounters. Managing Service Quality: An International Journal, 20(4), 328-342. doi:10.1108/09604521011057478

Wilkinson, S. (1998). On the nature of immersion during study abroad: Some participants' perspectives. Frontiers: The Interdisciplinary Journal of Study Abroad, 4(2), 121-138.

Ylanne, V. (2008). Communication accommodation theory. In H. Spencer-Oatey (Ed.), Culturally speaking: Culture, communication, and politeness theory (pp.164-189). New York: Continuum.

Appendix

Motivation Questionnaire Items (adapted from Dörnyei \& Taguchi, 2009)

\begin{tabular}{ll}
\hline Category & Items \\
\hline Criterion & If a French course was offered in the future, I would like to take it. \\
& I would like to use French even if I were not required to do so. \\
& I would not like to spend lots of time using French. \\
& I am not prepared to expend a lot of effort in speaking French. \\
& Compared to others, I think my efforts to use French are relatively strong. \\
Ideal L2 self & Whenever I think of my future career, I imagine myself using French. \\
& I can imagine a situation where I am speaking French with Quebecois. \\
& I cannot imagine myself speaking French with international friends or \\
& colleagues. \\
I cannot imagine myself speaking French as if I were a native speaker of \\
French. \\
I cannot imagine myself as someone who is able to speak French.
\end{tabular}

Ought-to L2 self Learning French is not necessary because people surrounding me do not expect me to do so.

Studying French is important to me in order to gain approval of my colleagues/spouse/family/friends/boss.

Studying French is important to me because an educated person is supposed to be able to speak French.

Studying French is not important to me because other people will not respect me more if I have knowledge of French.

It will have a negative impact on my life if I don't learn French.

(continued next page) 
Instrumentalitypromotion

Instrumentalityprevention

Attitudes toward learning French

Interest in the French language

French anxiety
Knowing French is not important to me because I think it will not be useful in getting a good/better job.

Studying French is important to me because with French I can work globally.

Knowing French is not important to me because I do not want to spend a longer period living abroad (e.g., studying and/or working in other Frenchspeaking areas).

Knowing French is important to me in order to attain a higher social respect.

The things I want to do in the future do not require me to use French.

I have to know French because without knowing French I cannot keep my current employment.

I do not have to know French because without knowing French I can still get a job.

I have to know French so I don't miss any job opportunities.

I have to know French or I cannot be successful in my career.

Knowing French is important to me because I don't want to be considered a poorly educated person.

I like the atmosphere of Montreal for speaking French.

I do not look forward to speaking French in Montreal.

I find learning French boring.

I really enjoy learning French.

Time drags while using French.

I feel excited when hearing French spoken.

I am not interested in the way French is used in conversation.

I find the difference between English vocabulary and French vocabulary interesting.

I dislike the rhythm of French.

I get nervous and confused when I am speaking French.

I am not afraid that others will laugh at me when I speak French.

I feel at ease speaking French with a native speaker.

If I met a French native speaker, I would feel nervous.

I would get tense if someone asked me for directions in French. 